\title{
RIGLYNE VIR DIE RESPIRATORIESE VERPLEGING VAN DIE KARDIO-TORAKALE PASIëNT IN DIE POST-EKSTUBASIE FASE
}

\section{Geertjie G de Beer}

MCur-student (Mediese en Chirurgiese Verpleegkunde: Kritiekesorgverpleging (Algemeen)), RAU

\section{Elzabe Nel}

DCur, Senior Lektor, Departement Verpleegkunde, Randse Afrikaanse Universiteit

Korresponderende outeur: wen@edcur.rau.ac.za

\section{Eben Arries}

MCur, Lektor, Departement Verpleegkunde, Randse Afrikaanse Universiteit

Sleutelwoorde: respiratoriese verpleging; kardio-torakale pasiënt; post-ekstubasie; riglyne

\section{UITTREKSEL}

Die kritieke sorgverpleegkundige is verantwoordelik en aanspreeklik vir hoë gehalteverpleging van die pasiënt wat koronêre vatchirurgie ondergaan het. Die gespesialiseerde respiratoriese verpleging van hierdie pasiënt in die onmiddellike post-ekstubasie fase is nog nooit nagevors nie. Die vraag ontstaan dus wat is die beste-praktykriglyne vir die respiratoriese verpleging, van 'n kardio-torakale pasiënt wat koronêre vatchirurgie ontvang het, in die onmiddellike post-ekstubasie fase. 'n Kwalitatiewe verkennende en beskrywende navorsingsontwerp is uitgevoer om die menings van kritieke sorgverpleegkundiges werksaam in kritieke sorgeenhede in privaathospitale in Pretoria, oor hierdie respiratoriese verpleging in te samel. Fokusgroeponderhoudvoering is gevoer en die data is aan geselekteerde kardiotorakale chirurge en 'n pulmonoloog vir validering voorgelê. Vervolgens is ' $n$ literatuurkontrole onderneem en riglyne vir die respiratoriese verpleging van die kardio-torakale pasiënt, tydens die post-ekstubasie fase, is geformuleer. Vier hoofdimensies is geïdentifiseer, naamlik kliniese fisiologiese data, kommunikasie, vroeë liggaamlike aktiwiteit en beskikbare hulpbronne. Daar word aanbeveel dat hierdie riglyne nasionaal gevalideer word en dat die gehalte van respiratoriese verpleging van kardio-torakale pasiënte in die post-ekstubasie fase bepaal word.

\section{ABSTRACT}

The critical care nurse is responsible and accountable for quality nursing care of the patient that has undergone cardiothoracic surgery. The specialised respiratory nursing care of these patients in the immediate post extubation phase, has never been researched. The question arises what are the best practice guidelines for the respiratory nursing care of the cardio-thoracic patient that has undergone coronary artery bypass, with specific reference to the immediate post extubation phase? A qualitative exploratory and descriptive research design was utilised. The views of critical care nurses working in private hospitals in Pretoria, on this specialised respiratory care of patients, were collected by means of a focus group interview. The data was exposed to two selected cardio-thoracic surgeons and one pulmonologist for validation purposes. A literature control was carried out and guidelines for the respiratory nursing care of the cardiothoracic patient within the post extubation phase, were formulated. Four main dimensions were identifified, viz clinical physiological data, communication, early physical activities and available resources. It is recommended that these guidelines be exposed to national validation and that the quality of respiratory nursing care of the cardio-thoracic patient in the post extubation phase, be determined.

\section{INLEIDING}

Hierdie artikel fokus op die post-operatiewe verpleging van die kritiekesorg pasiënt wat koronêre vatomleidingchirurgie ondergaan het, met spesifieke verwysing na die respiratoriese verpleging van hierdie 
pasiënt nadat hy/sy ge-ekstubeer is. Die kritieke sorgverpleegkundige is verantwoordelik en aanspreeklik vir die gehalteverpleging van hierdie pasiënt. Daar is egter verskeie gespesialiseerde dimensies van hierdie kritieke sorgverpleging, waarvan respiratoriese verpleging, ' $n$ belangrike komponent is.

Daar is verskeie metodes waarop koronêre vatomleiding chirurgie uitgevoer kan word. Die mees algemene metode is om die pasiënt op kardiopulmonale omleiding tydens chirurgie te plaas. Tydens kardiopulmonale omleiding bly die longe ongeventileerd en ondergeperfuseerd. Dit veroorsaak ' $n$ afname in longmeegeefbaarheid met gevolglike afname in die funksionele en residuele kapasiteit wat aanleiding gee tot atelektase van die alveoli. Die narkose en spierverslappers verlaag die longe se spontane statiese en dinamiese longvolumes (Hudak, Gallo \& Morton, 1997:414). Bogenoemde faktore kan aanleiding gee tot respiratoriese komplikasies in die post-operatiewe fase van die pasiënt wat koronêre vatomleiding chirurgie ondergaan het.

Literatuur en navorsing oor die respiratoriese verpleging/ hantering van pasiënte in die post-operatiewe fase van koronêre vatomleiding chirurgie, handel meestal oor die geïntubeerde pasiënt. Daar is weinig literatuur of navorsing beskikbaar oor die respiratoriese verpleging en hantering van die pasiënt in die onmiddellike postekstubasie fase. Die post-ekstubasie fase is ' $n$ kritieke fase waar komplikasies kan intree indien daar nie toepaslike hoë gehalteverpleging in die kritieke sorgeenheid gelewer word nie. In die praktyk bestaan daar ook nie "beste-praktykriglyne" ten opsigte van die hantering van die pasiënt post-ekstubasie nie - die kritieke sorgverpleegkundige handel na goeddunke gebaseer op ervaring in die eenheid. Die vraag ontstaan dus, watter riglyne behoort geformuleer te word vir die respiratoriese verpleging van die pasiënt wat koronêre vatomleiding chirurgie ondergaan het, met spesiefieke verwysing na die post-ekstubasie periode van kritieke sorgverpleging?

Die doel met hierdie artikel is om riglyne te formuleer vir die respiratoriese verpleging van die kardio-torakale pasiënt wat koronêre vatomleiding chirurgie ondergaan het, met spesifieke verwysing na die post-ekstubasie fase, binne die konteks van geselekteerde privaathospitale in Pretoria.

\section{TERMINOLOGIE}

\section{Riglyne vir respiratoriese verpleging}

Riglyne vir respiratoriese verpleging verwys na die bestepraktyk verplegingsinteraksies wat die gehalte van verpleging in die post-ekstubasie fase van respiratoriese verpleging, van 'n kardio-torakale pasiënt wat koronêre vatomleidingchirurgie ondergaan het, in die kritieke sorgeenheid reflekteer.

\section{Post-ekstubasie}

Post-ekstubasie verwys na die eerste 24 uur nadat die pasiënt se endotracheale buis verwyder is, nadat die pasiënt suksesvol van die ventilator gespeen is.

\section{Kardio-torakale pasiënt}

Die pasiënt wat in ' $n$ kritieke sorgeenheid verpleeg word nadat hy/sy koronêre vatomleiding chirurgie ondergaan het.

\section{NAVORSINGSONTWERP}

' $n$ Kwalitatiewe verkennende en beskrywende navorsingstrategie is binne die konteks van geselekteerde privaathospitale in Pretoria uitgevoer (Burns \& Grove, 1993:51). Die menings van kritieke sorgverpleegkundiges, oor die mees toepaslike dimensies en beste-praktyk verplegingsinteraksies, is by wyse van een fokusgroeponderhoud ingesamel (Krueger, 1994:57-59). Die navorser het as onderhoudvoerder opgetree en die volgende vraag is gevra: "Wat is u mening oor gehalte-respiratoriese verpleging in die postekstubasie fase van 'n kardio-torakale pasiënt wat 'n koronêre vatomleiding ondergaan het?" Veldnotas is tydens die fokusgroeponderhoud deur 'n navorser afgeneem (Wilson, 1989:434-436). Hierdie fokusgroeponderhoud is verbatim getranskribeer, gevolg deur ' $n$ inhoudsontleding aan die hand van die beginsels soos beskryf deur Tesch (in Creswell, 1994). Vervolgens is ' $n$ literatuurkontrole uitgevoer en riglyne is geformuleer.

Die teikenpopulasie is die kritieke sorgverpleegkundiges wat aktief in Pretoria in privaathospitale praktiseer en betrokke is by die post-operatiewe verpleging van pasiënte wat koronêre vatomleiding chirurgie ondergaan het, asook kardio-torakale chirurge en pulmonoloë wat 
status van die pasiënt, met ander woorde na die pasiënt se bloeddruk, polsspoed, sentraal veneuse druk en temperatuur. Dit was belangrik vir die deelnemers dat die pasiënt as ' $n$ geheel beraam en gemoniteer moet word.

Rodgers-Kinney, Rodgers-Parka \& Dunbar (1988:641) verwys na die monitering van hemodinamiese en kliniese parameters om post-ekstubasie tekens van hipoksie, naamlik tagipnee, gebruik van addisionele asemhalingspiere, tagikardie, hipertensie, disoriëntasie en 'n lae parsiële druk van arteriële suurstof $\left(\mathrm{PaO}_{2}\right)$, te identifiseer. Volgens Cannobio (1990:220 - 221) vind onvoldoende gaswisseling post-ekstubasie plaas as gevolg van hipoventilasie en ventilasie/perfusie abnormaliteite of veranderinge. Onvoldoende asemhalingspatrone kom ook verder voor as gevolg van die verminderde longmeegeefbaarheid, insnydingspyn en angs. Longklanke moet dus post-ekstubasie vier tot agt uurliks geëvalueer word om ontwikkelende atelektase en pulmonale kongestie betyds te identifiseer en te behandel. Albei die kardio-torakale chirurge was van mening dat alle vitale data minstens uurliks gemoniteer moet word. Alle vitale data, insluitende die bloeddruk, polsspoed, sentraal veneuse druk, temperatuur, perifere saturasie/perfusie en asemhalingspoed, moet in ag geneem word tydens die pasiënt se evaluasie postekstubasie. Uit hierdie data het die navorser ' $n$ riglyn geformuleer dat die kardio-torakale pasiënt, postekstubasie, se vitale data minstens uurliks gemoniteer moet word. Hierdie data moet geïnterpreteer word en die toepaslike verplegingsinteraksies moet uitgevoer word.

\section{Bloedgas-analise}

Die tydige en gereelde neem van 'n arteriële bloedmonster vir bloedgas-analise is belangrik, volgens die menings van die deelnemers aan die fokusgroeponderhoud. Twee van die deelnemers was egter ook van mening dat nie almal die arteriële bloedgasse korrek interpreteer nie, veral sekere komponente naamlik die alveolêre-arteriële suurstof drukgradiënt $(\mathrm{AaDO} 2)$ en die intrapulmonale verskuiwings aftakking ("shunt"). Drie van die fokusgroepdeelnemers was van mening dat alhoewel bloedgas-analise belangrik is, dit nie onnodig geneem moet word nie, veral as die finansiële aspek daarvan in ag geneem word. Hulle het wel saamgestem dat arteriële bloedgasse ten minste vier uurliks post-ekstubasie geneem moet word.

'n Arteriële bloedgas-analise stel die kritiekesorg verpleegkundige in staat om die toereikendheid van gaswisseling in die longe te evalueer (Holloway, 1993:167). Evans en Black (1995:59) dui aan dat dit noodsaaklik is om arteriële bloedgasse met gereelde tussenposes te evalueer veral in pasiënte met kroniese respiratoriese toestande, post-operatief en postekstubasie. Cannobio (1990:220) stel voor dat daar by post-kardiotorakale chirurgiese pasiënte arteriële bloedgasse verkry moet word om tekens van respiratoriese alkalose of asidose te beraam en om lae vlakke veneuse hemoglobien saturasie ( $\mathrm{SvO} 2)$, 'n verlaagde suurstofvervoer en 'n verhoogde suurstofverbruik, te identifiseer.

Die pulmunoloog en beide kardio-torakale chirurge was van mening dat arteriële bloedgasse minstens vier uurliks geneem en geïnterpreteer moet word. Die samestelling van arteriële bloedgasse word bepaal deur ventilasie, pulmonale bloedvloei en deur hoe die ventilasie met die perfusie in die longe vergelyk (Misasi \& Keyes, 1996:38). In gesonde volwassenes is daar slegs baie klein verskille in beide die ventilasie en die perfusie. Die wanaanpassing van ventilasie en perfusie veroorsaak ' $n$ verlaagde parsiële koolsuurgas ( $\mathrm{PaCO}_{2}$ ) verandering en verhoog die AaDO2 verskille. Volgens Holloway (1993:171) is die $\mathrm{AaDO}_{2}$ ' $n$ belangrike maatstaf waarvolgens hipoksie by pasiënte geïdentifiseer kan word. Eerstens kan die hipoksie ontstaan as gevolg van lae alveolêre suurstofdruk te wyte aan hipoventilasie en tweedens mag die alveolêre suurstofdruk normaal wees, maar die diffusie na die kapillêre vate mag ingeperk wees soos tydens 'n ventilasie/perfusie wanaanpassing ("mismatch") en verhoogde "shunting". Die kliniese belang van die $\mathrm{AaDO}_{2}$ is om hipoksie te identifiseer. In kamerlug is die normale $\mathrm{AaDO}_{2}$ minder as $15 \mathrm{~mm} \mathrm{Hg}$.

Die navorser het dus tot die gevolgtrekking gekom dat dit belangrik is vir die kritiekesorg verpleegkundige om 'n deeglike kennis te hê van arteriële bloedgas-analise om sodoende die pasiënt effektief te kan beraam en toepaslike verplegingsinteraksies uit te voer. Daar word dus voorgestel dat arteriële bloedgas-analise minstens vier uurliks gemoniteer en geïnterpreteer word. 


\section{Perifere saturasie/perfusie}

Teenstrydige menings in verband met die gebruik van die perifere saturasie/perfusie het tydens die fokusgroeponderhoud na vore gekom. Drie deelnemers was van mening dat die perifere saturasie nie akkuraat genoeg is om slegs met behulp daarvan die suurstof te speen nie, terwyl een deelnemer van mening was dat dit wel gebruik kan word mits die perifere saturasie dieselfde bly tydens spening en nie net aanvaar word dat dit goed is as die perifere saturasie bo $90 \%$ is nie. Die polsoksimetrie word gebruik om die perifere saturasie deurlopend te moniteer en dit is ' $n$ wyse waarmee hipoksie dadelik geïdentifiseer kan word (Adam \& Osborne, 1997:96). Die pulmonoloog is van mening dat die perifere saturasie nie akkuraat genoeg is om die pasiënt se suurstofkonsentrasie slegs met behulp daarvan te speen nie, maar dat die polsoksimeter ' $n$ belangrike moniteringsmeganisme is om episodes van hipoksie vinniger op te spoor en te behandel. Die perifere saturasie word grootliks beïnvloed deur die suurstofhemoglobien dissosiasie kurwe (Adam \& Osborne, 1997:96). Die vermoë van suurstof om te bind en te dissosieer van hemoglobien, bepaal die oksiginasie status van die pasiënt se weefsels (Dickson, 1995:55). Volgens Dickson (1995:55) is die tekens van weefselhipoksie rusteloosheid, angstigheid, disoriëntasie, verwardheid, bewussyn-onderdrukking, dispnee, hipoventilasie, sianose, tagikardie, disritmieë, hipotensie en verlaagde urienuitskeiding. Indien hierdie tekens by die pasiënt post-ekstubasie tydens spening voorkom, moet die spening onmiddellik gestaak en herevalueer word.

Volgens Clochesy, Breu, Cardin, Whittaker en Rudy (1996:247) het die aanvang van die gebruik van die polsoksimetrie om die hemoglobien saturasie $\left(\mathrm{SaO}_{2}\right)$ te beraam, die gebruik van die $\mathrm{PaO}_{2}$-waardes om eersgenoemde te bepaal, drasties verminder. Die deelnemers aan die fokusgroeponderhoud se menings was teenstrydig daarmee, daarin dat hulle die belang van die $\mathrm{PaO}_{2}$-waardes beklemtoon het. Die polsoksimetrie bepaal die waardes van die $\mathrm{SaO}_{2}$ en daarom is sy gebruik beperk in die beraming van die suurstof vervoer. Die voordele van die pols-oksimetrie is, minimale pasiëntongemak, pasiënt-veiligheid, verbruikersvriendelikheid en betroubaarheid (Rodgers-
Kinney et al. 1998:61). Volgens Wright en Shelton (1993:98) is die tekortkominge van die pols-oksimetrie verhoogde kostes verbonde aan weggooibare sensorparte/dele, potensiële kompressie-beserings tydens langdurige gebruik, oorbenutting wat kan lei tot die gebrek aan ventilasie-monitering, onbetroubaar op pasiënte tydens episodes van hipo-perfusie, kan nie

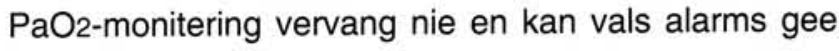
tydens beweging.

Die gevolgtrekking waartoe die navorser gekom het na aanleiding van die gegewe data, is dat die kardio-torakale pasiënt post-ekstubasie nie net met behulp van die perifere saturasie respiratories gehanteer kan word nie. Deurlopende perifere perfusie-monitering komplimenteer die neem van uurlikse vitale data en vier-uurlikse arteriële bloedgasse.

\section{X-Strale}

Die deelnemers aan die fokusgroeponderhoud se mening in verband met $X$-strale was dat infektiewe infiltrasies en basale atelektase alreeds op ' $n$ X-straal geïdentifiseer kan word en sodoende kan die pasiënt se respiratoriese verpleging/hantering daarvolgens aangepas word. Met X-strale verwys hulle spesifiek na die anterior-posterior liggende borskas X-straal. Borskas $X$-strale toon die posisie en grootte aan van ' $n$ moontlike letsel en dit identifiseer strukturele abnormaliteite wat die ventilasie en perfusie kan beïnvloed, soos byvoorbeeld ' $n$ pneumotoraks, hemotoraks, fibrose, atelektase en infiltrasies (Evans \& Black, 1995:85). By enige pasiënt wat in die aktiewe fase van respiratoriese distres is, moet daar daagliks ' $n$ borskas $X$-straal geneem word. Longveranderinge kan dus waargeneem word voordat die simptome ' $n$ aanvang neem (Daly, 1985:213). Volgens Wright \& Shelton (1993:81) kan X-straal inligting aan die praktisyn weergee in verband met die digtheid, brongiale oplossing of verdikking, fibrotiese merke, verdikking van die diafragmatiese pleura, konsolidasie, atelektase, pneumotoraks of subkutane emfiseem, pleurale vog, pulmonale edeem, kanker, hiperinflasie en trageale verplasing. $X$-strale dui verder die posisionering van indringende lyne en apparate (onderwaterdreineringsisteem) aan (Wright \& Shelton, 1993:82). Xstrale werk komplementêr saam met die vitale data, bloedgas-analise en perifere saturasie, om die pasiënt 
respiratories optimaal te verpleeg. Die navorser het eersgenoemde gevolgtrekking gemaak en dat X-strale op die geneesheer se versoek geneem moet word.

\section{Slaap en uitputting}

Slaaploosheid en uitputting gaan hand-aan-hand. Dit was die mening van die deelnemers aan die fokusgroeponderhoud dat die kardio-torakale pasiënt as gevolg van die omgewing (kritiekesorg eenheid) en die akuutheid van hulle toestand, nie voldoende slaap nie. Onvoldoende slaap lei tot psigiese en liggaamlike uitputting wat psigies presenteer met disoriëntasie, geïriteerdheid en afname in samewerking, wat weer lei tot uitputting, tagikardie en ' $n$ verlaagde pyndrempel. Volgens Holloway (1993:625) is medikasie, omgewingstimuli (byvoorbeeld ligte en geraas), pyn, vrees, angstigheid, immobiliteit (in vergeleke met die pasiënt se normale aktiwiteite), en die temperatuurveranderinge die hoof bydraende faktore tot slaapdeprivasie in kritiekesorg eenhede. Slaapdeprivasie, met gevolglike uitputting, kan lei tot liggaamlike en psigologiese simptome naamlik geheue verlies, disoriëntasie, geïrriteerdheid, verlaagde motivering (moraal), delusies en paranoïese of psigotiese gedrag. Slegs deur periodes van negentig minute se ononderbroke slaap toe te laat, is al voordelig vir die pasiënt. Daar moet ook gepoog word om aktiwiteite te groepeer in twee- tot vier-uurlikse roetines (Holloway, 1993:625).

Die personeel van ' $n$ kritiekesorg eenheid is bewus daarvan dat ' $n$ pasiënt se normale slaap- roetine versteur word en dat die personeel juis daarom en as gevolg van die erns van die pasiënt se toestand, moet probeer verseker dat die pasiënt voldoende slaap kry. Die personeel in De Jager (1996:74) se navorsingstudie in verband met agtergrondgeraas in ' $n$ intensiewesorg eenheid, het sterk aanbeveel dat vasgestelde slaap- en rustye streng gevolg moet word en dat ligte sover moontlik afgeskakel moet word om dit so donker as moontlik te maak sodat pasiënte makliker en gemakliker kan slaap. Tydens hierdie periodes moet die personeel hulle aktiwiteite tot die minimum beperk en toesighoudende aksies uitvoer (De Jager, 1996:74).

Vir die effektiewe respiratoriese verpleging van die kardio-torakale pasiënt tydens die post-ekstubasie fase, moet die verpleegkundige verseker dat die pasiënt voldoende rus en slaap kry. Dit is tot hierdie gevolgtrekking waartoe die navorser gekom het na aanleiding van gegewe data.

\section{Suurstofterapie}

Volgens die menings van die deelnemers aan die fokusgroeponderhoud vorm suurstofterapie ' $n$ belangrike komponent van die respiratoriese verpleging van die kardiotorakale pasiënt, post-ekstubasie. Die deelnemers het saamgestem dat die pasiënte post-ekstubasie op $60 \%$ suurstof begin moet word, hulle het wel verskil oor hoe lank die suurstofkonsentrasie op $60 \%$ gelaat moet word. Die meerderheid was van mening dat die suurstof so gou as moontlik gespeen moet word, terwyl een deelnemer van mening was dat die pasiënte vir ten minste twaalf uur $60 \%$ suurstof moet ontvang, ten spyte van bevredigende arteriële bloedgasse. Die pulmonoloog se mening in verband met suurstofterapie was dat die pasiënte post-ekstubasie op $60 \%$ suurstof begin word terwyl dit daarna so vinnig as moontlik gespeen word. Hy beklemtoon egter die individualiteit van elke pasiënt. Die primêre doel van suurstofterapie post-ekstubasie, is om hipoksie te herstel en te voorkom. ' $\mathrm{n} \mathrm{PaO}_{2}$ meer as sestig millimeter kwik is normaalweg voldoende indien die hemoglobienvlakke normaal is (Dossey, Guzzetta \& Kenner, 1992:215). Die suurstof kan toegedien word deur of ' $n$ nasale kanule wat sekere voordele inhou soos deurlopende suurstoftoediening sonder dat dit verwyder hoef te word wanneer die pasiënt eet of drink soos beskryf deur Garrard, Foëx \& Westaby (1997:769), of deur 'n gesigmasker wat gehumidifiseerde, verwarmde suurstof kan toedien soos beskryf deur Dossey et al. (1992:216).

Ten spyte van die voordele verbonde aan suurstofterapie, kan verskeie newe-effekte voorkom naamlik hipoventilasie, absorberende atelektase en pulmonale suurstof-toksisiteit (Dossey et al. 1992:216). Volgens Woodrow (2000:182) is die tekens van suurstof-toksisiteit pulmonale kapillêre sel swelling, interstisiële swelling, beskadiging van tipe-1 alveolêre selle (produseer surfaktant), voortdurende verlaging in longmeegeefbaarheid, hemorargiese en intra-alveolêre edeem, pulmonale fibrose, mukosilliëre veranderinge wat 
sputum retensie veroorsaak, alveolêre uitsetting en atelektase as gevolg van die stikstof verplasing en substernale pyn. Daar is egter nog nie bewys dat die toediening van hoë konsentrasies suurstof vir kort periodes skadelik is nie.

Die gevolgtrekking wat die navorser gemaak het is dat die aanwending van die kliniese indikatore soos die perifere saturasie en arteriële bloedgasse belangrik is by die toediening en spening van suurstofterapie, postekstubasie.

\section{Pynhantering}

Die deelnemers was almal van mening dat effektiewe pynhantering belangrik is in die respiratoriese verpleging van die kardio-torakale pasiënt, post-ekstubasie. Pasiënte wie se pyn onder beheer is herstel normaalweg beter aangesien hulle beter saamwerk met die behandeling, byvoorbeeld tydens fisioterapie en mobilisasie. Een van die deelnemers het besondere klem gelê op pro-aktiewe optrede tydens pynhantering, met ander woorde die pasiënt moet gereeld sy pynmedikasie ontvang en nie eers wag totdat hy pyn het nie. Vir die meeste deelnemers was morfiensulfaat die middel van keuse, maar dit hang egter van die geneesheer se voorskrif af.

Die pulmonoloog was van mening dat die pasiënt glad nie pyn moet hê nie. Beide chirurge is van mening dat analgetika streng volgens voorskrif gegee moet word en nie slegs op pasiënt aanvraag nie. Die kritieke sorgverpleegkundige moet die pasiënt noukeurig beraam vir tekens van bewussyn-onderdrukking. Melzack en Wall (in Woodrow, 2000:72) beskryf die "Gate Control" teorie. Dit word beskryf as 'n hek ("gate") wat oop, toe of geblokkeer kan wees. Wanneer dit oop is, gaan die stimuli na die hoër sentrums toe. Indien die hek toe is, verhoed dit die impulse om deur te gaan en so word geen pyn ervaar nie. Endogene analgetika beheer hierdie hek, byvoorbeeld serotonien verhoog pyntoleransie en deur die manipulasie, aanvulling of vervanging van hierdie analgetika, kan pyn gekontroleer word.

Volgens Woodrow (2000:72) word die persepsie van 'n ontvangde stimuli beïnvloed deur psigologiese faktore soos die pasiënt se kultuur, verwagtinge (vorige ervarings, angs en misinterpretasies) en afleiding. Pyn is ' $n$ belangrike faktor om die simpatiese respons van verhoogde katesjolamines produksie, naamlik vasokonstriksie, verhoogde bloeddruk en tagikardie, uit te lok. Vasokonstriksie en tagikardie sal die kardiale werkslas verhoog en die koronêre arterie vullingstyd verkort. Beide hierdie reaksies is nie ideaal vir die postoperatiewe herstel van die kardiale funksies nie (Adam \& Osborne, 1997:194). Pynverligting is om hierdie rede besonder belangrik en behoort ' $n$ hoë prioriteit van verpleging te wees. Akute pyn kan daartoe lei dat die slaappatroon versteur word en dit benadeel die helende rol wat slaap speel. Akute pyn lei tot ' $n$ afname van slaap, wat beteken dat daar ' $n$ afname in die stadige slaapgolf en vinnige oogbewegings (REM) is. Die moegheid wat ontstaan as gevolg van die versteurde slaap, mag erge psigologiese gevolge tot gevolg hê, soos byvoorbeeld die afname in motivering en die ontstaan van depressie (Klopper, 1996:32).

Volgens Klopper (1996:86) se navorsing in verband met pynhantering van pasiënte na ernstige chirurgie, is die beginsels van pynbeheer dat akute pyn 'n unieke individuele ervaring is, met die persoon wat die pyn ervaar as die kundige. Pasiënte moet ten alle tye betrokke wees by die besluitnemingsproses om die gevoel van afhanklikheid te verminder, die verpleegkundige moet doeltreffende pasiënt voorspraak lewer deur as advokaat vir die pasiënt op te tree en die voor- en nadele van die spesifieke pynhanteringsmetode moet ondersoek word sodat metodes aangepas kan word. Die pasiënt moet as 'n geheel (liggaam en gees) hanteer word en samewerking tussen alle lede van die multidissiplinêre span lei tot optimale gesondheidsorg. Voorligting en onderrig aan die pasiënt is belangrik vir samewerking (Klopper, 1996:86).

Pynhantering is dus belangrik tydens die respiratoriese verpleging van die kardio-torakale pasiënt, postekstubasie. Dit was die gevolgtrekking waartoe die navorser gekom het terwyl sy ook daarvan bewus is dat sekere kulturele en persoonlike faktore asook fisiese faktore in aanmerking geneem moet word tydens die pynhantering van hierdie kategorie pasiënte.

\section{KOMMUNIKASIE}

Kommunikasie was die volgende hoofkategorie wat vanuit die data van die fokusgroeponderhoud 
geïdentifiseer was. Interaksie word as die sub-kategorie beskryf.

\section{Interaksie}

Die deelnemers se mening was dat effektiewe interaksie ' $n$ belangrike komponent vorm van die respiratoriese verpleging van die kardio-torakale pasiënt, postekstubasie. Sommige deelnemers was van mening dat effektiewe interaksie pre-operatief al begin. Interaksie impliseer die voorspraak wat die verpleegkundige by die geneesheer doen vir die pasiënt met betrekking tot die pasiënt se toestand en behandeling soos deur die Praktykregulasies van die Suid-Afrikaanse Raad op Verpleging voorgeskryf word (Regulasie 387 en Regulasie 2598, soos gewysig). Volgens Rogers-Kinney et al. (1988:433) kan die waarde van effektiewe interaksie in die kritiekesorg eenheid waargeneem word deurdat dit die pasiënt se uitkoms verbeter, dit bevorder familiepersoneel verhoudinge en dit bevorder ook personeelpersoneel verhoudinge. Pasiënte wat weet wat om te verwag, met ander woorde voortdurende interaksie en voorligting, werk beter saam met hulle behandelingsprogram (Adam \& Osborne, 1997:193).

Die gevolgtrekking waartoe die navorser gekom het, is dat dit die kritieke sorgverpleegkundige se taak is om interaksie, dit wil sê kommunikasie, in stand te hou. Kommunikasie is dus belangrik in die respiratoriese verpleging van die kardio-torakale pasiënt, postekstubasie.

\section{VROEË LIGGAAMLIKE AKTIWITEITE}

Vroeë liggaamlike aktiwiteit is as hoofkategorie uit die fokusgroeponderhoud se data geïdentifiseer. Die subkategorieë wat hierdie hoofkategorie steun is fisioterapie en vroeë mobilisasie en ook die positiewe eindekspiratoriese druk masker.

\section{Fisioterapie en vroeë mobilisasie}

Een van die fokusgroep-deelnemers was van mening dat fisioterapie nie net die verantwoordelikheid van die fisioterapeute is nie, maar ook elke kritieke sorgverpleegkundige se verantwoordelikheid, veral in die aand. Die deelnemers was van mening dat nebulisering, diep asemhalingsoefeninge en veral ook vroeë mobilisasie post-ekstubasie belangrik is.

Cannobio (1990:221) stel voor dat die pasiënt aangemoedig en ondersteun moet word tydens hoespogings en diep asemhalingsoefeninge. Hierdie oefening moet twee tot vier uurliks gedoen word. Ondersteun die borskas met ' $n$ kussing om die gepaardgaande pyn te verdof. Hierdie aktiwiteite is daarop gemik om die sekrete te mobiliseer, om die longuitsetting te bevorder en om post-ekstubasie atelektase te voorkom en herstel. Verder stel Connobio (1990:221) voor dat die pasiënt so gou as moontlik gemobiliseer moet word en borskas-perkussie moet ontvang.

Nebulisering en humidifikasie word gebruik om sekrete te bevogtig en te verdun sodat die pasiënt dit makliker en met minder inspanning kan uithoes. Tydens nebulisering is stadige diep asemhalings noodsaaklik vir optimale effektiwiteit. Hierdie tipe asemhaling verhoog die ventilasie van die geobstrukteerde areas en help sodoende die groter aërosol druppels om dieper in die longe in te gaan (Keller, Solomon \& Reyes, 1984:65). Volgens Garrard et al. (1997:769) is voldoende pynverligting, ondersteuning en aanmoediging om te hoes om sekrete te verwyder, uiters noodsaaklik in die handhawing van goeie post-ekstubasie respiratoriese funksie.

Fisioterapie moet dus ten minste vier-uurliks gedoen word, volgens die navorser se gevolgtrekking. Dit is noodsaaklik dat fisioterapie deur die dag en nag voortgesit word en vroeë mobilisasie is voordelig vir die pasiënt. Die navorser het verder tot die gevolgtrekking gekom dat effektiewe pynbeheer noodsaaklik is vir die effektiwiteit en sukses van fisioterapie en vroeë mobilisasie.

\section{Positiewe Eind-ekspiratoriese Druk-Masker (PEED)}

Die positiewe eind-ekspiratoriese druk-masker is vanuit die fokusgroepdata geïdentifiseer as belangrik in die respiratoriese hantering van die kardiotoraks pasiënt, post-ekstubasie. Die deelnemers was bewus daarvan dat PEED van toepassing is op die geventileerde pasiënt en dat die deurlopende positiewe lugweg druk ("continuous positive airway pressure" - CPAP) van toepassing is op die geëkstubeerde pasiënt, maar 
aangesien PEED hulle gebruikstaal vir CPAP was, was PEED vir die doel van die navorsing gelyk aan CPAP. Hulle was van mening dat PEED eerder vroeër as later begin moet word, met ander woorde sodra die arteriële bloedgas monster ' $n$ verhoogde $\mathrm{AaDO}_{2}$ en "shunt" vertoon. Dit was die deelnemers se mening dat PEED vyftien minute uit elke uur toegedien moet word en dat die nodige voorligting en psigiese ondersteuning noodsaaklik is vir die sukses van die PEED-masker.

Dit was die pulmonoloog se mening dat die PEEDmasker besonder effektief is in die behandeling van basale atelektase en konsolidasie, maar hy was terselfdertyd ook van mening dat die PEED-masker nie noodwendig herïntubasie kan voorkom as die pasiënt erg respiratories gedistres raak nie. Die kardio-torakale chirurge het saam met die pulmonoloog gestem dat die PEED-masker begin moet word sodra die $\mathrm{AaDO}_{2}$ en die "shunt" verhoog, dieselfde as die fokusgroep onderhoud deelnemers, en dat die PEED-masker longbelugting en oksiginasie verbeter deur ' $n$ vergrootte alveolêre oppervlak daar te stel vir gaswisseling. Volgens Wright en Shelton (1993:39) is PEED ' $n$ metode om die ekspirasie van die totale intrapulmonale gasse te verkry deur ' $n$ verhoging in die longvolume deur die handhawing van ' $n$ eind-druk gradiënt waarby vloei nie verder kan plaasvind nie.

Die PEED-masker moet styf pas rondom die neus en mond en is besonder ongemaklik en daarom moet die pasiënt wakker wees en samewerking gee (Gerrard et al. 1997:769). Potensiële komplikasies van die PEEDmasker sluit in aspirasie, gastriese dilatasie en druk op die gesig wat ongemak en weefsel nekrose kan veroorsaak (Dossey et al. 1992:225). Die kliniese doel van PEED is om ' $n$ PaO2-waarde van groter as sestig tot sewentig millimeter kwik te handhaaf met ' $n$ suurstof konsentrasie van $50 \%$ of laer met geen noemenswaardige verlaging in die kardiale uitwerp nie (Rodgers-Kinney et al. 1988:832).

Die navorser maak die volgende gevolgtrekking, naamlik dat die PEED-masker effektief gebruik kan word tydens die respiratoriese verpleging van die kardio-torakale pasiënt, post-ekstubasie.

\section{BESKIKBARE HULPBRONNE}

Vir die uitvoering van optimale verpleging is die korrekte hulpbronne noodsaaklik. Die hulpbronne wat geïdentifiseer is uit die gegewe data is finansies en toerusting.

\section{Finansies}

Al die deelnemers aan die fokusgroeponderhoud was verbonde aan privaat-hospitale en dit was dus hulle mening dat finansies altyd belangrik geag moet word. Dit was hulle mening dat prosedures wetenskaplik gegrond moet wees en nie slegs uit roetine uitgevoer word nie. Hulle mening was ook dat alle kritieke sorgverpleegkundiges vertroud moet wees met die sienings, beperkinge en vereistes van die mediese fondse. Kritieke sorgverpleging moet verskaf word waar begunstigde uitkomste teen ' $n$ aanvaarbare koste bereik kan word. Die definiëring van begunstigde uitkomste en aanvaarbare kostes is heel dikwels problematies. Ironies dat hoër finansiële druk gepaard gaan met konstante hoër verwagtinge van die publiek (Woodrow, 2000:527). Kritieke sorgkostes word steeds hoër ten spyte van gestabiliseerde begrotings en die al hoër kostes verbonde aan gesondheidsorg. Die suksesvolle hantering van eenvoudiger toestande, byvoorbeeld enkel-orgaanversaking, het aanleiding gegee tot die ontstaan van meer komplekse toestande, byvoorbeeld multi-orgaanversaking, wat beide die koste per dag en die durasie van hospitalisasie verhoog het.

Volgens Walleck (in Wlody, 1994:197) moet toepaslike kwaliteitsversekerings-standaarde ontwikkel word om die hoogste moontlike kwaliteit verpleging te verskaf met die beskikbare hulpbronne. Onnodige praktyke en die wangebruik van sekere dienste wat uitgeskakel of verminder kan word, terwyl die effektiwiteit in die praktyk behoue bly en die gebruik van kliniese navorsing om die praktyk te verander, is noodsaaklik.

Die navorser het die gevolgtrekking gemaak dat gehalteverpleging verskaf moet word wat koste-effektief sowel as besparend van aard is.

\section{Toerusting}

Die menings van die deelnemers aan die fokusgroeponderhoud was dat aangesien toerusting en die instandhouding daarvan groot finansiële implikasies 
vir die privaat-hospitaal het, is dit belangrik dat hierdie toerusting korrek gebruik word en dat dit akkuraat en betroubaar is. Die deelnemers was van mening dat die toerusting in gebruik nie altyd akkuraat is nie, byvoorbeeld die polsoksimeter. Verskeie polsoksimeters verskaf ' $n$ indikasie van hoe sterk die waargenome sein is, sodat die verbruiker die kwaliteit van die meting kan evalueer. Indien die hartspoed van die polsoksimeters verskil van die werklike hartspoed, moet die perifere saturasie ook onder suspisie geplaas word (Wright \& Shelton, 1993:97). Soos in geval met die suurstoftoedieningstelle, indien dit foutief is, kan dit ernstige nagevolge vir die pasiënt inhou. Volgens Keller et al. (1984:54) is dit belangrik dat aërosol suurstof-toerusting elke vier ure getoets moet word of dit die korrekte suurstofkonsentrasie toedien. Selfs in die geval van die bloedgas-analiseerders verskil die waardes tussen verskillende apparate en gee nie almal al die lesings nie, byvoorbeeld die $\mathrm{AaDO}_{2}$. Dit is dus vir die kritieke sorgverpleegkundige noodsaaklik om vertroud te wees met die omgewing en ook die toerusting waarmee hy/sy gaan werk.

Die akkuraatheid van toerusting moet vier uurliks bepaal word en alle toerusting moet gereeld gediens word om akkuraatheid te verseker.

\section{RIGLYNE VIR RESPIRATORIESE HANTERING VAN DIE KARDIOTORAKS PASIËNT, POST-EKSTUBASIE}

Die volgende riglyne is deur die navorser geformuleer:

1. Die kritieke sorgverpleegkundige moniteer die vitale data van die kardio-torakale pasiënt, post-ekstubasie, uurliks ten opsigte van die hartspoed, ritme, bloeddruk, sentraal veneuse druk, asemhalingspoed, temperatuur en vir tekens van gebruik van die addisionele asemhalingspiere, hipoksie en die perifere saturasie. Longbelugting word vier- tot agt uurliks geobserveer en alle observasies moet geïnterpreteer word.

2. Die kritieke sorgverpleegkundige moniteer die kardiotorakale pasiënt, post-ekstubasie, se arteriële bloedgasse tydens die spening van suurstofkonsentrasie ten minste vier uurliks.

3. Die kritieke sorgverpleegkundige moniteer die kardio- torakale pasiënt, post-ekstubasie se perifere saturasie deurlopend en gebruik dit komplimentêr tot die vitale data en arteriële bloedgasse in die beraming van die pasiënt.

4. Die kritieke sorgverpleegkundige neem X-strale op versoek van die geneesheer en indien respiratoriese nood teenwoordig is.

5. Die kritieke sorgverpleegkundige dien $60 \%$ suurstof toe aan die kardio-torakale pasiënt, post-ekstubasie en speen die suurstof konsentrasie met behulp van die kliniese indikatore, naamlik die perifere saturasie en die arteriële bloedgas-analises.

6. Die kritieke sorgverpleegkundige beraam en beheer die kardio-torakale pasiënt, post-ekstubasie se pyn effektief tydens die respiratoriese verpleging van hierdie pasiënte deur kulturele, persoonlike en fisiese faktore in aanmerking te neem.

7. Die kritieke sorgverpleegkundige tree op ' $n$ voortdurende basis in interaksie met die geneesheer om voorspraak te doen vir die kardio-torakale pasiënt, postekstubasie om die pasiënt se gesondheid te bevorder. Die kritieke sorgverpleegkundige bied psigiese ondersteuning aan die pasiënt.

8. Die kritieke sorgverpleegkundige koördineer die toepassing van fisioterapie en sit dit voort in die nag en laat die pasiënt twee ure post-ekstubasie begin mobiliseer, indien hemodinamies stabiel.

9. Die kritieke sorgverpleegkundige wend die PEEDmasker aan wanneer die kardio-torakale pasiënt, postekstubasie se $\mathrm{AaDO} 2$ en "shunt" begin verhoog en hy/ sy dien die PEED-masker vyftien minute uit elke uur toe, maar laat die pasiënt vir ten minste vier ure in die nag slaap mits die pasiënt se arteriële bloedgasse dit toelaat.

10. Die kritieke sorgverpleegkundige is bewus van die finansiële implikasies tydens die respiratoriese verpleging van die kardio-torakale pasiënt, post-ekstubasie en voer kwaliteit, dog koste-besparende verpleging uit.

11. Die kritieke sorgverpleegkundige is vertroud met die hantering van die toerusting wat tydens die respiratoriese verpleging van die kardio-torakale pasiënt, postekstubasie, gebruik word en toets die toerusting vir 
akkuraatheid volgens die instandhoudingsinstruksies.

\section{GEVOLGTREKKINGS EN AANBEVELINGS}

Die fokus is op die toepaslike monitering van vitale data - die aard en frekwensie daarvan, optimale kommunikasie met die pasiënt, die fasilitering van vroeë liggaamlike aktiwiteite en die hantering van optimale benutting van beskikbare hulpbronne. Die volgende aanbevelings word gemaak:

\section{Verpleegpraktyk}

- Die riglyne vir die respiratoriese verpleging van die kardio-torakale pasiënt, post-ekstubasie, moet in die praktyk geoperasionaliseer en geïmplementeer word.

- Die gehalte van respiratoriese verpleging in die postekstubasie fase van die kardio-torakale pasiënt moet bepaal word.

- Noukeurige rekordhouding, deurlopende herevaluering en deurlopende kommunikasie tussen al die betrokke partye is noodsaaklik vir die kontinuïteit van die behandeling.

\section{Verpleegonderrig}

- Die respiratoriese verpleging van die kardio-torakale pasiënt, post-ekstubasie moet wetenskaplik gegrond wees en aksies wat uitgevoer word moet daarvolgens gerig wees.

- Indiensopleiding en onderrig is noodsaaklik in kritieke sorgverpleegkunde sodat op datum gebly kan word met die nuutste navorsing.

\section{Verpleegnavorsing}

- Nadat die riglyne geoperasionaliseer en geïmplementeer is, moet dit wetenskaplik getoets en indien nodig, aangepas word.

- Die riglyne moet aan nasionale validering blootgestel word.

- Verdere studies oor die metodes van suurstoftoediening is nodig.

- Studies oor die tipe fisioterapie wat die kritieke sorgverpleegkundige met die beste effektiwiteit kan toepas is nodig.

- Navorsing moet gedoen word oor die kritieke sorgverpleegkundige se kennis van die interpretasie van borskas $\mathrm{X}$-strale en arteriële bloedgasse.

- Navorsing oor die respiratoriese verpleging van die kardio-torakale pasiënt, post-ekstubasie, in ander geografiese gebiede en hospitale is nodig.

\section{BEPERKINGE}

Die navorsing was uitgevoer binne die konteks van privaat-hospitale in Pretoria en dit beïnvloed die studie se oordraagbaarheid na ander geografiese gebiede. Die gebrek aan navorsingsinligting spesifiek gerig op die post-ekstubasie fase van hierdie pasiënte is ' $n$ verdere beperking. Die deelnemers aan die fokusgroeponderhoud het telkens na die geïntubeerde pasiënt verwys en die onderhoudvoerder moes deurlopend uitklaring oor die spesifieke fase van respiratoriese verpleging doen.

\section{VERWYSINGS}

ADAM, SK \& OSBORNE, S 1997: Critical Care Nursing Science \& Practice. Oxford: Oxford University Press, Oxford Medical Publications.

BURNS, N \& GROVE, S 1993: The Practice of Nursing Research: Conduct, Critique and Utilization; second edition. USA: WB Saunders Company.

CANOBBIO, MM 1990: Cardiovascular Disorders, Mosby's Clinical Nursing Series. United States of America: The CV Mosby Company. CRESWELL, JW 1994: Research Design, Qualitative and Quantitative Approaches. Thousand Oaks, California: Sage.

CLOCHESY, JM; BREU, C; CARDIN, S; WHITTAKER, AA \& RUDY, EB 1996: Critical Care Nursing; second edition. Philadelphia: WB Saunders Company.

DALY, BJ 1985: Intensive Nursing Care, Current Clinical Nursing Series; second edition. New York: Elsevier Science Publishing Company.

DE JAGER, L 1996: Agtergrondsgeraas In 'n Intensiewe Sorg Eenheid (M.Cur Mediese en Chirurgiese Verpleegkunde: Kritieke Sorg: Algemeen.) Johannesburg: Randse Afrikaanse Universiteit.

DICKSON, SL 1995: Understanding the Oxyhemoglobin Dissociation Curve. Critical Care Nurse, October 1995:54-58.

DOSSEY, BM; GUZZETTA, CE \& KENNER, CV 1992: Critical Care Nursing, Bodymind-spirit; third edition, Philadephia: JB Lippincott Company.

EVANS, MJ \& BLACK, MA 1995: Surgical Nursing: second edition. Springhouse, Pennsylvania: Springhouse Corporation.

GARRARD, C; FOËX, P \& WESTABY, S 1997: Principles and Practice 
of Critical Care. Osney Mead, Oxford: Blackwell Science Ltd.

HOLLOWAY, NM 1993 : Nursing the Critical III Adult; fourth edition. United States of America: Addision - Wesley Nursing (A Division of The Benjamin Cummings Publishing Company Inc).

HUDAK, M; GALLO BM \& MORTON P, 1997: Critical Care Nursing, a Holistic Approach, 7th edition. Philadelphia: Lippincott.

KELLER, C; SOLOMON, J \& REYES, AV 1984: Respiratory Nursing Care. Englewood Cliffs, New Jersey: Prentice-Hall Inc.

KLOPPER, S 1996: Pynhantering van die Pasiënt na Ernstige Chirurgie. (M.Cur Intensiewe Algemene Verpleegkunde) Johannesburg: Randse Afrikaanse Universiteit.

KRUEGER, RA 1994: Focus Groups, A Practical Guide for Applied Research; second edition. Sage Publication.

LINCOLN, YS \& GUBA, EG 1985: Naturalistic Inquiry. Sage Publications.

MISASI, RS \& KEYES, JI 1996: Matching and Mismatching Ventilation and Perfussion in the Lung. Critical Care Nurse, 16(3), June 1996:2338.

ROGERS-KINNEY, M; RODGERS-PACKA, D \& DUNBAR, BS 1988: AACN's Clinical Reference For Critical Care Nursing; second edition. New York: McGraw Hill Book Company.

STREUBERT, HJ \& CARPENTER, Dr 1995: Qualitative Research In Nursing Advancing The Humanistic Imperative. Philadelphia: JB Lippincott Company.

SUID-AFRIKAANSE RAAD OP VERPLEGING (SARV) 1984: Regulasies Betreffende die Bestek van Praktyk van Persone wat kragtens die Wet Op Verpleging, 1978, Geregistreer of Ingeskryf Is (R2598, soos gewysig).

SUID-AFRIKAANSE RAAD OP VERPLEGING (SARV) 1985: Reëls wat die Handelinge of Versuime, ten opsigte waarvan die Raad Tugstappe kan doen, uiteensit (R387, soos gewysig R866).

WILSON, HS 1989: Introduction Research in Nursing. California: Addison-Wesley Nursing.

WLODY, GS 1994: Managing Clinical Practice In Critical Care Nursing. St Louis: Mosby.

WOODROW, P 2000: Intensive Care Nursing, A Framework from Practice. London: Routledge.

WRIGHT, JE \& SHELTON BK 1993: Desk Reference for Critical Care Nursing. Boston: Jones \& Bartlett Publisher, Inc. 